European journal of American studies

Special Issue: Spectacle and Spectatorship in American Culture

"Somebody do Something!": Lynching

Photographs, Historical Memory, and the Possibility of Sympathetic Spectatorship

Amy Louise Wood

C OpenEdition

Journals

Electronic version

URL: https://journals.openedition.org/ejas/15512

DOI: $10.4000 /$ ejas. 15512

ISSN: 1991-9336

Publisher

European Association for American Studies

Electronic reference

Amy Louise Wood, "'Somebody do Something!": Lynching Photographs, Historical Memory, and the Possibility of Sympathetic Spectatorship", European journal of American studies [Online], 14-4 | 2019, Online since 23 December 2019, connection on 08 July 2021. URL: http://journals.openedition.org/ ejas/15512 ; DOI: https://doi.org/10.4000/ejas.15512

This text was automatically generated on 8 July 2021

Creative Commons License 


\title{
"Somebody do Something!": Lynching Photographs, Historical Memory, and the Possibility of Sympathetic Spectatorship
}

\author{
Amy Louise Wood
}

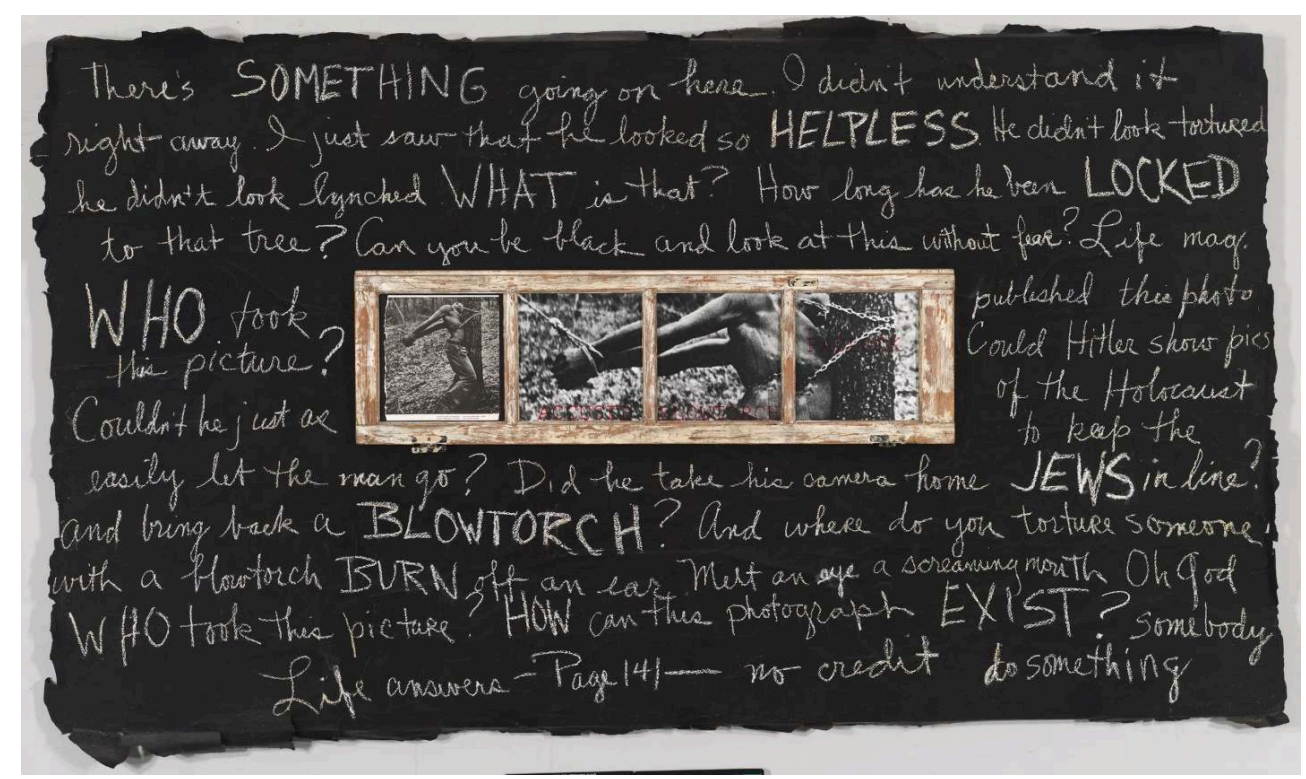

Figure 1: Pat Ward Williams, "Accused/Blowtorch/Padlock" (1986). Digital Image OWhitney Museum of Art/Licensed by Scala/Art Resource, NY.

“There's something going on here. I didn't see it right away" reads the text. And so the artist compels us to look closely. At the center of the piece, in a row, sit four panels of photographs, each bordered with a wooden frame. With more scrutiny, it becomes clear that the four images are pieces of the same photograph. A black man is tied to a tree. It is an image that is both grossly familiar-as the text says, "you've seen one 
lynched man, you've seen them all"-and strangely jarring. After all the man is not hanging from a tree; he even appears to be still alive, as the tension in his legs suggests he is bearing some of his own weight.

2 What the piece does not tell us is that this man, named Robert "Bootjack" McDaniels, 26 years old, was lynched in 1937 in Duck Hill, Mississippi. He was apparently a bootlegger who, along with his compatriot, Roosevelt Townes, had been whipped and threatened by local whites for his illegal activities. When a local merchant was murdered, the two men became prime suspects and were arrested. As they were being led to the county courthouse to stand trial, a mob of about 200 white men kidnapped them, took them to a clearing in the woods, beat them, and cut them with knives. The mob then used gasoline blowtorches on them to extract their confessions. Once satisfied, the mob shot McDaniels to death and burned Townes alive. A third suspect, Everett "Shorty" Dorrah, had been brought to the clearing to watch, before he was horsewhipped and ordered to leave the state. ${ }^{1}$

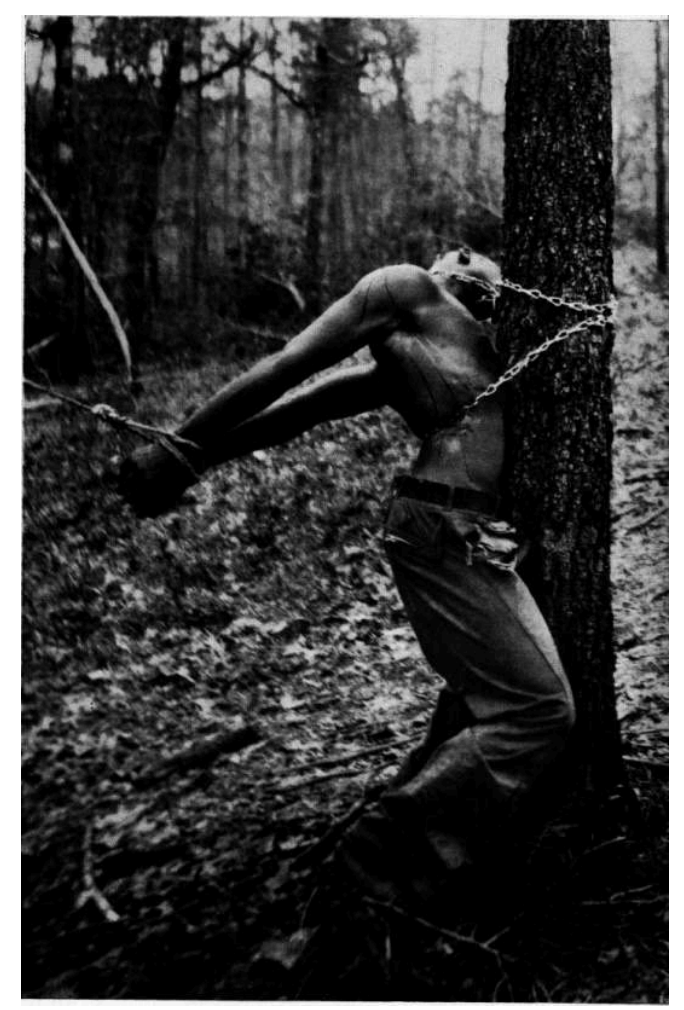

Figure 2: Robert "Bootjack" McDaniels, April 13, 1937

3 A local photographer documented this sequence of events and sold selected images out of his studio in Grenada, Mississippi. These images, which include the one in Figure 2, as well as another of Townes hogtied to a tree, differ from the conventions of most lynching photographs in that they depict the torture being enacted, rather than capturing its aftermath or even an interrupted or staged moment in the process. The lynchers are not visible, as they are in many such photographs, in which mobs stood proudly around their victims, but their presence is clearly felt in the tug of the chains that bind McDaniels' hands, pulling his body away from the tree.

Some fifty years later, in 1986, African-American artist Pat Ward Williams used this image of McDaniels in the piece shown in Figure 1, entitled, "Accused, Blowtorch, Padlock." Williams is a conceptual artist who works in a variety of media, weaving 
together historical and autobiographical images that deal with memory and race in America. Her work also impels viewers to physically and intellectually interact with the art, which is what she wants us to do in encountering this piece. ${ }^{2}$ She has surrounded the panels of photographs with a series of questions and statements that challenge not only the lynching, but the act of photographing it. Her text asks, "Did he take the camera home and then come back with the blowtorch?," evoking a metaphorical association between the camera and the weapon as instruments of violation. ${ }^{3}$ She also contests those who would exhibit such an image by reproaching Life magazine for publishing the photograph, which it did in 1937 and then again in 1955 (the page number she gives, p. 141, refers to the 1955 publication), and suggests that Life's editorial decision was ideologically loaded with real-world political effects: "Life magazine published this picture. Could Hitler show pics of the Holocaust to keep the JEWS in line?" In other words, publishing the image was a means of racial control.

The form of Williams' text, not only its content, expresses a sense of personal outrage. The words are handwritten, scrawled and shaky, connoting not written language but speech, and angry speech. It is a shouting voice, screaming to be heard above the power of the violent image. And then the scrawl of text ends with "Somebody do something," written in the present tense, as if she asking the viewer to intervene in the scene or respond in some way to what is happening in the photograph.

Several things are happening in this piece. First, Williams collapses any distinction between the torturer and the act of photographing or even exhibiting an image of that torture. Then, in her final statement, she collapses past and present. The torture is ongoing; it exists in the present. These two points are related, since her text implies that the continued existence of the photograph extends the victim's torture. Moreover, Williams emphasizes the emotional impact-the affect-that viewing this torture produces. That affect, as manifest in both the content and the form of the text, is visceral, and its physical intensity calls upon us to feel sympathy, as in to feel with or alongside (sym-) the suffering (pathos) of another. Our sympathy is twofold; we are horrified by the sight of the victim's torture, but also we feel alongside the artist -in fact, it's her suffering that calls out to us directly.

8 This piece is a memorial to lynching, to the horror of thousands of African Americans tortured and killed throughout the Jim Crow era. Lynching has served as the primary metaphor, or what Leigh Raiford has called the "primal narrative," through which African Americans have interpreted their subjugated status in the US and have responded to racial injustice in the present. ${ }^{4}$ If lynching is a primal metaphor, lynching photographs have served as the visual symbols of that metaphor. As such, they have the capacity to activate popular consciousness about racist violence in the past and guide public discourse about it by producing in the viewer a meaningful ethical engagement with that past, what many scholars have termed "bearing witness." ${ }^{5}$ As Ann Kaplan has argued, viewing another's suffering becomes an act of witnessing when one is so emotionally aroused by the scene that one is transformed to the point of feeling "vaguely responsible" and thus motivated to act. Kaplan terms this emotional response one of empathy, as the viewer imagines him/herself in the moment-though, as I explain below, I prefer the term sympathy. An ethical engagement need not entail a direct intervention, but can consist of a shift in perspective of the world and one's own responsibilities in it. ${ }^{6}$ 
9 But what does it mean to bear witness to past atrocities? Can the spectatorship of a historical image of racial suffering produce a sympathetic, and thereby ethical, engagement with present-day injustice? The status of lynching photographs as symbolic forms, as icons, I believe, opens up the possibility of such encounters. That iconic status strips the photograph of any historical specificity, so that its subject comes to represent something greater than itself. ${ }^{7}$ Removed from history, the photograph remains ever-present, speaking to ongoing injustice and trauma. What's more, its iconic status renders the spectator's relation to the image somewhat fluid. New meanings can be imposed on an image through text, framing, and context, as well through the viewer's subjective positioning, all of which can potentially reposition the spectator to stimulate an affective response, not only to the lynching victim, but to those suffering in the present. In other words, lynching photographs can help create an ethical historical memory of racial violence, engaging with the past to reflect upon the present and demanding a reckoning with present-day injustice. This is what, for African Americans, Raiford has called "black critical memory," an interpretation of the past that forms black political and social identities and mobilizes social justice movements. ${ }^{8}$ But, I contend, lynching photographs also create the possibility of a white sympathetic encounter with the historical memory of lynching. In that context, Williams' plea for "somebody [to] do something" in the face of Townes' long-past torture does not seem out of time or place.

10 By historical memory, I am referring to ideas that groups and individuals might hold about past events that they never experienced or witnessed first-hand. These memories are, by their very nature, social. For one, they come to be framed, learned, and transmitted through groups and institutions in families, schools, museums, and the media-acts of transfer that make remembering possible at all. That is, there exists no understanding or mental image of historical events outside social representations of them. What's more, social groups make decisions about what is memorable and what is not, often to meet the needs and concerns of the present. In other words, historical memories derive only from present-day social judgments about what is important to apprehend and convey. The formation of historical memories is, to be sure, a contested process, as whose memories come to dominate in the public sphere is dependent on social power, and that process can also entail misremembering and even forgetting. This is especially so in the context of histories of race and violence in the United States, as various social groups hold very different memories of this past, which, in turn, structure their responses to present-day racial violence. ${ }^{9}$ In particular, while for many black Americans the memory of lynching is visceral and ever-present-that "primal narrative"-for many white Americans it is hazy, distorted, or forgotten. Yet that misremembering can be disrupted through self-reflective acts of displaying and looking at lynching photographs, much as Williams does in "Accused/Blowtoch/Padlock."

11 This paper will consider the creation of an ethical historical memory of racist violence in the United States by tracing the exhibition history of the photograph of Bootjack McDaniels' torture and murder. It reflects on the ways in which text and context can shape affect and, in turn, sympathetic engagement. It will also consider public responses to lynching photographs more broadly to argue that, although black and white spectators tend to respond to these photographs in different ways, whites can engage in a parallel process of critical memory through a form of sympathetic spectatorship..$^{10}$ 
We are well aware today that a photograph is not a transparent or objective reflection of an event; that is, the documentary realism of photography is somewhat of an illusion. A photograph represents only a snapshot of time; it does not tell us what happened before and after the moment or what is happening outside the frame, nor can it capture sound or mood. Yet, despite these limitations, photographs have an unusual capacity to construct and transmit historical memories of an event, especially so with acts of atrocity such as lynching. That capacity is undoubtedly due to the authority we bestow on photographs as objective records of the past. Unlike oral or written accounts of the past, a photograph appears not to have a mediator, especially as the subjective position that is inherent in any photograph-the eye of the cameraperson-is concealed. The authority granted to a photograph is compounded in instances of human atrocity, which challenge our assumptions about imaginable human behavior. Through its indexical function, the photograph provides the proof that violence demands; we know that this event took place because somebody was there to capture it on film. ${ }^{11}$ The supposed realism and immediacy of that image prompts an emotional response that sears itself into memory. Photographs of atrocity can shock the viewer out of complacency-horrify, repel, and sadden.

Indeed, rather than casting doubt on the past, the fact that photographs represent only a defined moment in time contributes to their capacity to facilitate historical memories. Those memories depend on some sort of tangible manifestation that condenses what is actually a complicated and ambiguous past into an accessible form and brings conflicting group or individual recollections into a schematic, conventional unity. ${ }^{12}$ Photographs stabilize the past into an unchanging and easily readable image, what Susan Sontag has likened to a "quotation, or a maxim, or a proverb." ${ }^{13}$ They have, in that sense, what has been called an "iconic presence," making present a moment through representation that is otherwise lost to time. The "iconic presence" speaks also to the aura around a photograph, through its intrinsic association with death, or a moment lost in time, so they appear as a ghostly remnant of the past. ${ }^{14}$ In that sense, photographs operate much like memory itself, bringing to life the past in a shadowy, yet vivid-immediate, yet approximate-way.

15 Many public responses to Without Sanctuary, a collection of over 100 photographs, many of which were published in 2001 and have been exhibited in various cities over the past eighteen years, attest to this authority that lynching photographs hold. In his forward to the book, Without Sanctuary, Congressman John Lewis writes that, although as a child growing up in Alabama he heard stories about lynchings, they "seemed nightmarish, unreal-even unbelievable." The photographs, however, "make real the hideous crimes that were committed against humanity.... [and] bear witness especially since many Americans will not (don't want to) believe such atrocities happened in America." ${ }^{15}$ In other words, photographs force an ugly truth on a reluctant and disbelieving public and provide them a visual vocabulary through with which to comprehend this violence. Viewers of the Without Sanctuary collection in various exhibitions across the country and online have recorded similar responses. The images, viewers claim, offer a "realistic representation" of lynching, a "brutal truth and reality" that "burn[s] the idea into our heads to remember." They are "disturbing" and "bone-chilling," yet "eyeopening," revealing the full scale of the horror for viewers. As one viewer posted, "I knew our past was a horrible and dark time, but I never imagined it looked like this." ${ }^{16}$ 
Yet these qualities of atrocity photographs are precisely what make them problematic as vehicles for historical memory, as many critics have pointed out. ${ }^{17}$ As Williams makes clear in her piece, the violence represented in the image is bound up in the act of photographing, a fact that heightens the sickening horror of the images. Lynching photographs thus make an individual's death-already horrific not only because of the torture he suffered, but because that suffering was made public so casually-public once again. The sensationalism of the image potentially renders the present-day viewer a voyeur, another lynching spectator. The lynching victim, in turn, is rendered an anonymous icon, a representation of all black suffering, frozen in time, the effect of which is to potentially reify black victimhood..$^{18}$

What's more, some have argued, repeated exposure to atrocity images can anesthetize viewers from the past trauma represented in them, a distancing which ultimately produces ethical or political indifference. ${ }^{19}$ Encountering the images in the quiet comfort of a gallery or in the security of their homes, viewers are potentially offered a screen from any real engagement from the horror of the moment. And the representation of the event ultimately comes to replace any real understanding or knowledge of it. Instead, the images can feed a simplistic narrative of the past and prompt conventional, predictable responses to it. ${ }^{20}$

These challenges inherent in the exhibition of atrocity photographs have led to an impulse not to look, to remove the images from view. ${ }^{21}$ John Lewis has said that his wife refuses to open the book version of Without Sanctuary. ${ }^{22}$ This same impulse can be seen in the work of contemporary artists such as Kerry James Marshall and Ken GonzalezDay, who, unlike Williams, have grappled with the relationship between memory and lynching photography by recreating the images in their work, yet obscuring the bodies of the dead in them..$^{23}$ The National Memorial for Peace and Justice, which the Equal Justice Initiative (EJI) opened in Montgomery, Alabama, in 2018 to commemorate the victims of lynching, includes no photographs, to haunting effect. At the center of the site is a large, semi-enclosed square containing 800 steel slabs, each representing 800 counties in which lynchings were committed. They are suspended from the ceiling frame, as if to resemble hanged bodies. Elsewhere on the six-acre lot, replicas of the slabs are laid on the ground, lined up in rows, appearing like coffins. The omission of photographs was intentional. As EJI executive director Bryan Stevenson told the Montgomery Advertiser, "I think for some people 'Without Sanctuary' created this optic that was shocking, and we were less interested in shocking optics." The EJI wanted to emphasize the communities in which this violence took place, rather than suffering of individual victims. ${ }^{24}$ Indeed, the EJI will deliver to any county its slab to be displayed on site as a memorial. In doing so, the hope is that communities will take responsibility for their history, that is, to bear witness. Yet, would the EJI memorial be as evocative and powerful as it is if viewers did not already know what a lynching looked like? $* * *$

The history of the Duck Hill photo can be instructive in formulating how to look at lynching photographs in a way that leads to an ethical engagement with the historical memory of lynching. Lynching photographs were detached from historical specificity and rendered into symbols from their very first appearances. For the defenders of lynching, they could stand as representations of white supremacy and power over black beastliness. For anti-lynching activists, they became symbols of white barbarism and the failure of American democratic ideals. ${ }^{25}$ As a photograph moves in and out of 
different visual and ideological contexts, it comes to reflect the needs of a particular moment in time. ${ }^{26}$ This was true of the photograph of Bootjack McDaniels' lynching, long before Williams used it in "Accused/Padlock/Blowtorch."

21 In 1937, it was the first photograph of a lynching of a black man to be published in the mainstream, national press. ${ }^{27}$ This lynching attracted relatively significant national attention at the time because it occurred just as the U.S. House of Representatives was debating the passage of the Gavagan Bill, a bill that would make lynching a federal crime, thereby allowing the federal government to place sanctions upon communities in which a lynching took place. This bill, introduced by New York Congressman Joseph Gavagan, a white man who represented black Harlem, was one of many similar attempts to pass anti-lynching legislation in the 1920s and 1930s. The Gavagan Bill passed the House 277-118, largely along sectional lines, a legislative victory that was helped by the news of the Duck Hill lynching. ${ }^{28}$ Time magazine reported that, two days before the vote, debate in the House "rose to a furious crescendo" after one representative read from a press report the details of the torture enacted upon Townes and McDaniels. ${ }^{29}$ McDaniels and Townes were to stand in for all lynching victims at that moment, and their lynching was the kind of atrocity an anti-lynching bill was meant to punish.

Soon afterwards, Life magazine published the photograph of Bootjack McDaniels' tortured body, flanked on either side by headshots of Congressmen Gavagan and Hatton Summers (D-TX), the lead opponent of the bill, with the headline "One Lynching Spurs Congress to Stop Others,"-a positioning meant to direct the viewers' interpretation of not only the lynching photograph as one with high political stakes, but also the bill itself: this is the kind of atrocity over which these men were battling. ${ }^{30}$ Time magazine similarly published another photograph from the Duck Hill lynching, one that showed both McDaniels and Townes, naked and hogtied to a tree, in the frame, beside its story about the Gavagan Bill. ${ }^{31}$ Then, in December of that year, when the same bill was being debated in the Senate, a poster that included both images appeared outside the Senate chamber. It also was published in the Chicago Tribune amidst a series of ads and a photograph of a black dance performance [see figure 3]..$^{32}$ Beyond brief captions, most of these outlets provided few details about the lynching itself, or McDaniels and Townes, or their alleged crime..$^{33}$ But to serve their purpose, these images did not require context; they were meant to serve as a visual rallying cry to garner support for the bill. The Memphis Press-Scimitar, which also printed the photograph of McDaniels alone, did so "only in hope that it will cause such a feeling of revulsion that there will never be another like it." ${ }^{34}$ 


\section{THESE BLOW TORCH LYNCHINGS Occurred While the Wagner-Van Nuys Anti-Lynching Bill Was Pending Before the Congress

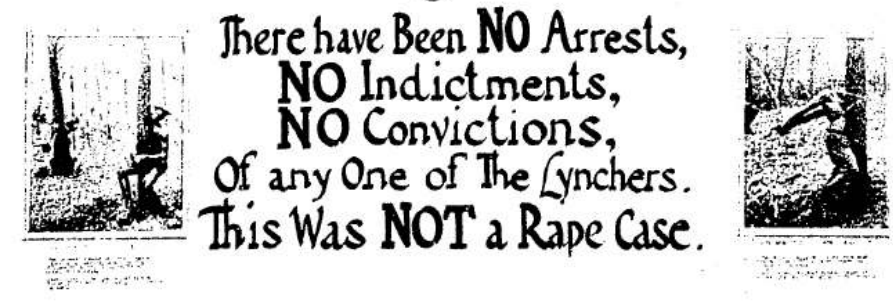

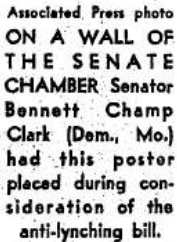

Figure 3: Chicago Tribune, 5 December 1937, H2

The press's use of the Duck Hill photographs were very much in line with how the black press and the NAACP had been using lynching photographs for years. Since Ida B. Wells first printed an illustration of a lynching, rendered from a photograph, in her 1894 anti-lynching pamphlet, A Red Record, activists had used lynching images to provide visual documentation to a potentially disbelieving public that these atrocities were happening, and to arouse "revulsion" in viewers as a means to galvanize the antilynching movement. In doing so, they displaced these photographs entirely from the local circumstances and sentiments that had produced them. The authenticity or journalistic specificity of the images were not that important to them. They rarely offered any details about the victims, and provided little context for their murders. Often one lynching photograph would be used in many different contexts, with the name and date of the victim erased from the images. The NAACP furthered this practice when it began publishing lynching photographs in its newspaper, the Crisis, and in various anti-lynching pamphlets and posters. For anti-lynching activists, the photographs served as interchangeable symbols of white brutality and black suffering. ${ }^{35}$ Their efforts substantiate the notion that the meaning of a photograph is not intrinsic to the image; rather, meaning is created-an emotive reaction producedthrough the ideological context in which it is viewed.

This use of lynching photographs fit with activists' broader rhetoric, which placed emphasis not on black victimhood, but on the depravity of white mobs. Lynching, activists tended to argue, was a crime not so much against black communities or families but against American civilization and democracy. Their political rhetoric and imagery made surprisingly little mention of race or racial prejudice. In fact, the black victim-a too-visible reminder of black criminality-became largely eclipsed, while the members of the mob, as defilers of justice and law, moved to the front and center of anti-lynching discourse. These editorial decisions appealed to white liberals and 
moderates who might harbor fears about black criminality, but who also believed in law and order, and wanted to see America as a civilized and just nation. In that context, it made sense not to provide readers with any details about the victims or the events that allegedly precipitated the lynching. Photographs depicting only the lynched man's body were exceptional in the black press for that reason; editors often preferred photographs that showed the surrounding mob. ${ }^{36}$

Eighteen years later, in January 1955, the photograph of McDaniels' lynching appeared as part of the Family of Man exhibition at the Museum of Modern Art in New York, organized by photographer Edward Steichen. The exhibition included a large assortment of images from across the world that depicted a wide array of human experiences, and was accompanied by a book, also entitled Family of Man, which has been in print ever since. The exhibit derived from a post-war liberal and modernist impulse that sought to draw connections between diverse human experiences as universal experiences-to see, in Steichen's words, "the essential oneness of mankind throughout the world." ${ }^{37}$ Ascribing authenticity to the photographic images, Steichen imagined that photography could reveal essential human truths. Rather than pictorial representations produced from distinct human subjectivities, Steichen believed that the images in the exhibition could act as direct reflections of fundamental human realities, mirrors "of the universal elements and emotions in the everydayness of life." ${ }^{38}$ The exhibit was arranged thematically, beginning with photographs depicting love and sexuality, progressing to birth, childhood, and other moments of celebration, and then turning to darker moments of war, violence, and finally death. The photographs were hung on the bare white walls of the museum with no context, on the assumption that the images spoke for themselves. ${ }^{39}$

The Duck Hill lynching photograph was actually removed from the Family of Man exhibition soon after it opened and did not appear in the book. The image was apparently attracting too much attention, thereby disrupting the exhibition's overall theme of collectivity and universality. According to Steichen's assistant at the time, Wayne Miller, "the theme of the show [would be] interrupted by this individual photograph.... the presentation [of the photograph] was dissonant to the composition." ${ }^{40}$ Indeed, as John Szarkowski has noted, the exhibit was designed to be a holistic experience, in which all 500 photographs were to "speak with one voice."41 Although Steichen seemed more concerned with the impact of the photograph on the exhibition, rather than on the prospective viewer, his decision to excise it from the show acknowledged, on some level, that in 1955 lynching could not be reduced to a collective human experience, and that to display such an image within the context of this exhibition was to diminish its horror. 


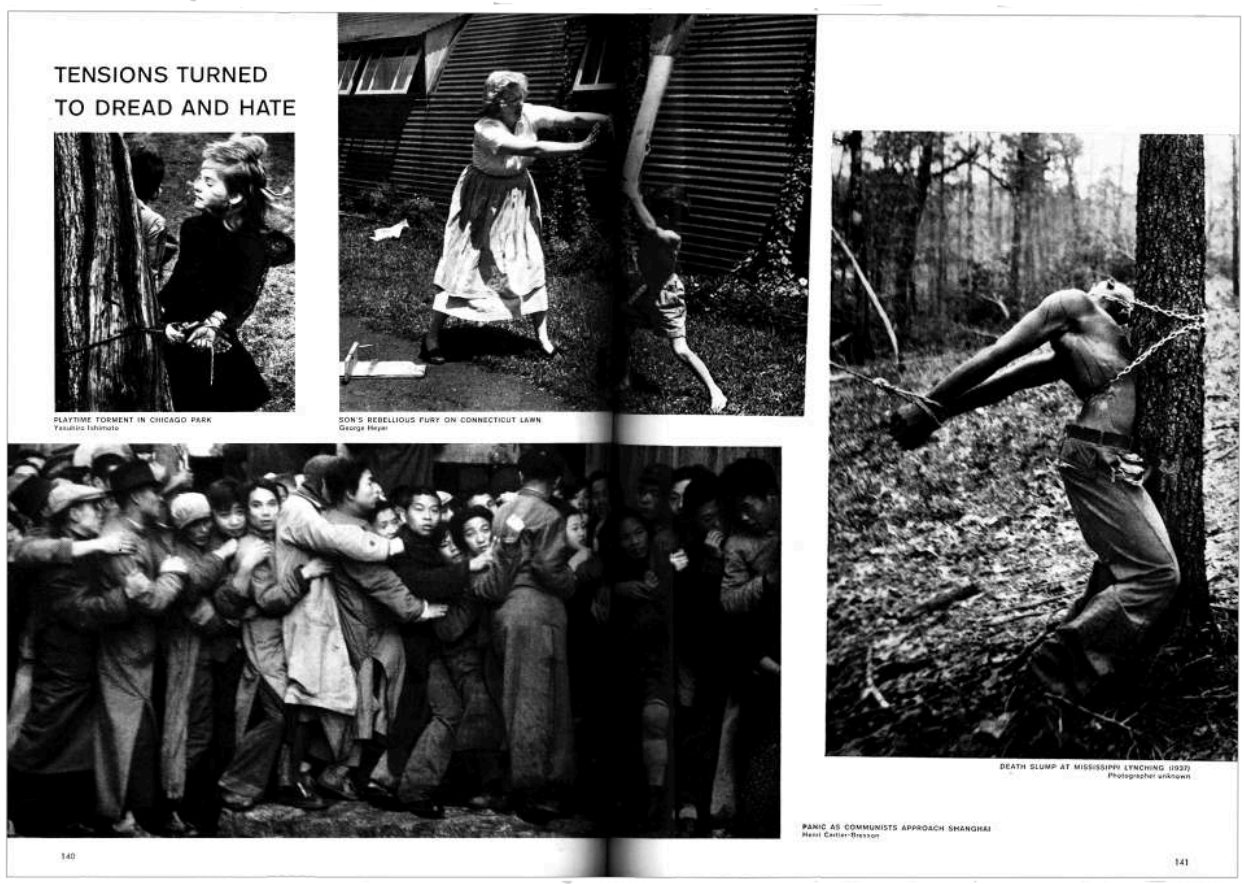

Figure 4: Life Magazine, 14 February 1955. Henri Cartier-Bresson, “China,” CMagnum Photos; Yasuhiro Ishimoto, "Little Ones," CKochi Prefecture, Ishimoto Yasuhiro Photo Center; reproduced with permission.

Before Steichen had the image permanently removed from the exhibition, however, Life magazine chose to publish it as part of a Family of Man photographic essay in February 1955 in conjunction with the MOMA exhibition. Since many of the images in the exhibition had been borrowed from Life's archives, the exhibition was as much an advertisement for Life as the magazine's photo-essay was a promotion for the show. Besides its commercial ties to the collection, Life, with a comfortable, white middleclass readership of about six million, was a suitable venue in which to promote the exhibition; Steichen's vision matched Life's entire moral and aesthetic approach to news. In its introduction to the photo-essay, Life announced that the pictures portray "the emotions which all members of the human family share, no matter in what country or at what stage of civilization they live," anticipating that its viewers would reflect upon the similarities and continuities between diverse human experiences. ${ }^{42}$

The image of Bootjack McDaniels' tortured body appeared on a two-page spread, entitled "Tensions Turn to Dread and Hate," along with three other photographs: a crowd scene before the Communists invaded Shanghai; a scene in which a young boy, having a tantrum in suburban Connecticut, swings a board at his mother; and, diagonally opposite the lynching photograph, a photo captioned, "Playtime Torment in Chicago Park," in which two white children are tied to a tree in some sort of game. [See figure 4.] These images were not presented together in Steichen's exhibition or in his book; these juxtapositions were Life's editorial decision. Through them, lynching, and by extension ongoing racial conflicts in America, were conflated with Cold War anxiety and postwar suburban unrest.

In placing the image of McDaniels' torture with these other images, Life replaced its original racial and political significance with another, arguably just as menacing, ideological meaning. The effect of this placement was to equate otherwise 
incomparable experiences of human pain and suffering. Perhaps the juxtaposition of two children tied to a tree in a game and a man being tortured to death was intended to suggest an underlying terror in childhood play. Yet instead, the tragedy of lynching was diminished, rendered into another "domestic" conflict with which Life readers, largely white and middle-class, were meant to identify.

The caption Life chose for the photograph-"Death Slump at Mississippi Lynching, 1937"-also serves to unburden the image of its racist origins. It tersely relates the time, place, and event so that the image comes to signify something much broader than McDaniels' lynching, becoming a generalized representation of suffering. The phrase "Death Slump" is particularly jarring. The phrase directs the viewer's response to the image by reimagining the violence that is represented; in fact, it elides the violence. The caption suggests the man is dead, but, as noted, a closer look reveals he's notquite. "Slumping" and "death" do not connote murder, and certainly not torture, but rather a spontaneous or natural loss of life. "He suddenly slumped over," we might say. Viewers in 1955 could read this caption and look at this image without absorbing the knowledge that this man was being tortured to death. Any emotional impact of the image is weakened, and viewers could remain comfortable in their own detachment from injustice. Unlike the use of this photograph at the height of the anti-lynching movement, this placement entirely disregarded lynching as a specific historical practice perpetrated against African Americans.

What is significant here, however, is not that the reprinting of the photograph itself caused any numbing effect in viewers; rather, the context in which it is situated allows viewers a voyeuristic glance while remaining disengaged. Yet the historical and social position of the viewer also matters. After all, looking at this image in the present day, viewers are likely to be horrified, not only by the photograph, but by Life's seemingly casual editorial decisions. Perhaps in 1955 viewers would have been able to immediately contexualize this image in the light of current racial conflicts-though this photo-essay was released some seven months before the murder of Emmett Till and about ten months before the Montgomery Bus Boycott. ${ }^{43}$

It was not until 1986, when Pat Ward Williams used it for her piece, that the photograph of McDaniels' lynching appeared again in a public setting. Williams has stated in reference to this piece, "I raise the question of responsibility in the print media... I ask the viewer to think about what he thinks when he sees this image. Is it information or terrorism?" 44 In other words, the photograph provides historical evidence of an act of terrorism (i.e.: it is information), but the photograph itself functioned as an instrument of terror. In her question, and in the piece itself, she provokes viewers to become aware of their potential complicity in this act of terrorism as spectators, even consumers, of it. Yet in protesting the exhibition of this image, Williams herself makes a public presentation of it. In order to transform the image from an act of terrorism to a protest against terrorism, she must shift its meaning through her arrangement of the photograph, the text she attaches to it, and the spaces in which she chooses to exhibit it. As one critic noted, her recontextualization rendered her use of the photograph very different from "a member of the KKK finding the same image and tacking it up on his wall." ${ }^{45}$ In that sense, Life's error, one that leads Williams to accuse the magazine of terrorizing intent, was not that it published the photograph, but that it did so in ways that did not detach the photograph enough from its original, 
white supremacist meaning, or, alternatively, by detaching it too much from that context.

Williams' caption, "Accused/Blowtorch/Padlock," directs the viewer's response to the four images of McDaniel's lynching at the center of the piece, and, in doing so, replaces the historical erasure of the Life caption. While the phrase "death slump" elided the actions of the lynch mob, Williams places the emphasis back upon the perpetrators by naming their objects of torture. The term, "accused" could presumably function in several different ways. It could refer to McDaniels, who was referred to as the "accused" in contemporary news accounts. ${ }^{46}$ But placed before the words "blowtorch" and "padlock," and situated alongside her accusatory text, the "accused" can be understood as the men who tortured McDaniels and took this picture, or Life magazine that published it, or even the viewer gazing upon it. In that sense, her title forces a moment of self-reflection on the spectator.

The scrawled words and the wooden, three-dimensional frames with which Williams surrounds the images also direct the viewer's interpretation of those images, compelling us to share her horror at the atrocity before us. ${ }^{47}$ Alluding to the term "sound-bite," one reviewer referred to these scratches of phrases as "word-bites" that Williams supposedly borrowed from snippets of commentary she had read or heard over the years. ${ }^{48}$ "Word-bites" aptly connotes violence and fury. Replacing "word" with "sound" also describes our encounter with them; we do not hear them but read them, as our eyes are compelled to pour over her words, much as they pour over the images. The frames serve to separate the images from her text. One reviewer has likened the frames to windows that allow viewers to enter into the experience of human suffering in the images ${ }^{49}$ Lucy Lippard, similarly, has argued that the window frames, which Williams has used in other works, compel us "to look through it and enter into the picture's reality." These commentaries interpret Williams' intention as similar to Life magazine's presentation of the photograph. That is, the photo serves as an entry into an experience of human suffering with which viewers are meant to empathize. At the same time, Lippard says that the frames serve as a "distancing device," suggesting that viewers can remain inoculated against that suffering. ${ }^{50}$

It might actually be more useful to think of these frames not as window frames that provide entries into shared human experiences, but as picture frames. As such, they denaturalize the images of McDaniels' tortured body and signify that they are pictorial representations; that is, the images are constructed from a subjective and ideological point of view-that of the lynch mob-which reminds us that the violence is bound up in the photograph itself. The frames thus serve to highlight the conflation of the act of torture and the act of representing or exhibiting that torture, and make viewers aware that they are spectators of both. If the frames do distance viewers from the images, they do so not to anesthetize them from McDaniels' suffering, but, much as the text does, to remind them of their own complicity in it.

Williams' arrangement of the images similarly makes conspicuous the links between the act of lynching, the act of photographing the lynching, and the act of watching a lynching. Williams had divided the photograph of McDaniels' lynched body into individual body parts, effectively ripping it out of its context in order to recontextualize it. The division also replicates visually the destruction and objectification of McDaniels' body that the lynching itself enacted. The images literally break McDaniels apart, just as the lynch mob did. As viewers, we are then forced to 
reenact and confront the essential violation of this torture. The close-up shots of McDaniels' body verify that it is indeed a human body that is being violated-a hand, a torso, a neck, a face. The effect appears to be objectifying, but since it draws attention to the mob's objectification of McDaniels, the effect actually serves to re-humanize him. In challenging the viewer in these ways, Williams' piece does not allow for any aesthetic distancing or voyeuristic complacency.

Although Williams situates the photograph of McDaniels' lynching firmly within the history of racism and racist violence in the United States, the piece does not particularize this lynching. Viewers do not learn McDaniels' name, when this happened and where, or even what exactly is happening to him. Like the anti-lynching activists of the early twentieth century, she renders McDaniels' death into iconography. His death is to stand in for all African-American suffering; his torturers for all white racismincluding ongoing racial violence in the 1980s. Certainly, this image would have had particular resonance in 1986, when a series of high-profile crimes against African Americans led many activists and political leaders to publicly declare racial violence a rising problem. ${ }^{51}$ In 1982, a white gang had beaten Willie Turks to death in Brooklyn. In 1983, Michael Stewart was killed from blunt force trauma while in police custody in New York after his arrest for spraying graffiti in a subway station. A NYPD officer shot Eleanor Bumpers in her Bronx apartment in 1984. That same year, Bernhard Goetz generated national controversy when he shot four black teenagers, paralyzing Darrell Cabey permanently, after they approached him for money in the New York subway. Many white Americans hailed Goetz as a hero for his vigilante stand against the purported plague of black crime, while others, including the New York Police Commissioner, likened his act to a lynching. In 1986, a group of white teenagers beat and chased three black men, including Michael Griffith, in Howard Beach, Queens, forcing Griffith to run into traffic, where he was killed-an event New York mayor Ed Koch called a "modern lynching." ${ }^{2}$ The sense Williams conveys in "Accused/ Blowtorch/Padlock" that the lynching of McDaniels is happening now, and that someone can intervene, was, therefore, not entirely theoretical or rhetorical.

These events all happened in the context of national debates over hate crimes legislation that imposed harsher penalties on crimes committed due to racial or ethnic bias. Many states began passing hate crime laws in the 1970s and 1980s, and the US Congress began debating the first federal hate crimes legislation in 1985. As Christopher Waldrep has argued, the difference between a lynching and a hate crime is largely semantic. The term "hate crime," however, places the culpability for the violence on individual perpetrators, rather than an entire community, as the term "lynching" does. The effect on African Americans is nevertheless the same, for a hate crime or a lynching both arouse that terrifying sense of racial fear; in short, they terrorize. ${ }^{53}$ Williams' use of the term "terrorism" is thus pointed in this context. And by implicitly directing viewers to draw connections between past and present-day lynchings, she challenges the rhetoric of "hate crimes" to demand a sense of collective white responsibility.

39 At the same time, Williams shows awareness of the dangers of detaching lynching photographs from history. "There's something going on here. I didn't see it right away. After all, you see one lynched man you've seen them all," her text reads. "You've seen one lynched man you've seen them all"-the phrase implies that one anonymous victim can stand for all the rest; it's the multiplicity of the atrocity that matters, not the 
individual. But the phrase also draws attention to the common concern that, bombarded with atrocity photographs, present-day viewers can begin to overlook them or suffer from compassion fatigue. Yet, by juxtaposing "I" and "you" in the construction of these sentences, Williams aligns herself with her viewers' potential indifference and then impels them out of that apathy to participate with her in protest, to read the rest of her text.

Just above the wooden frames, Williams' text reads, "Can you be BLACK and look at this?," suggesting that a black viewer will feel particularly horrified and violated by the image. Her question evokes that "primal narrative," that visceral feeling of identification with the lynching victim and a sense that the terror of lynching persists in the present. Elizabeth Alexander has written movingly of how black racial identity has been forged through a collective traumatic memory of physical vulnerability, a "bottom-line blackness" that can obscure class, regional, generational, and other differences between African Americans. That memory, which "resides in the flesh," is re-activated by visual scenes of black suffering, a feeling echoed in "Blowtorch/ Accused/Padlock," as well as in many black viewers' responses to Without Sanctuary. ${ }^{54}$ As Hilton Als wrote in his introduction to the collection, "I felt my neck snap and my heart break, while looking at these pictures." ${ }^{55}$ One African American teacher said of the collection, "When I look at those pictures... I don't just see a lifeless body. I look at those pictures, and I see my son, I see my brother, I see my father. If I'm looking at that lifeless figure long enough, I see myself." ${ }^{56} \mathrm{An}$ interactive display at the 2012 exhibition in Charlotte, North Carolina, of one photograph of a mass lynching, asked visitors, "Where would you be in this photograph?" and prompted to them to record their answers on Post-It notes to display next to the photograph. Many black viewers wrote "I would be hanging from the tree." In addition, as Als points out, lynching photographs remind black viewers of their own objectification -that they are the objects of the white gaze, never the subjects of looking. Indeed, historically, the power of looking at black bodies in pain belonged to whites. ${ }^{57}$

But what of non-African-American viewers? What of white viewers today? Some black commentators have assumed that white Americans largely respond to these images with indifference or even complicity, a generalization that supposes a monolithic white interpretation. For example, emphasizing the bearing of the past on the present, Hilton Als intimates that white spectators implicitly identify with the members of the lynch mob or its white spectators, for, as a black man, he is excruciatingly aware that, to many whites, he is viewed as a potential criminal, a threat. He has been "lynched by eyes," he writes. "It's that experience of being watched and seeing the harm in people's eyes-that is the prelude to becoming a dead nigger," he tell us. ${ }^{58}$ It is true that many white viewers are reluctant to draw those connections, in part because time and context has led them to feel detached from the unmitigated white supremacy of Jim Crow America. On their Post-It notes at the Charlotte exhibit, white visitors invariably wrote that they would be "at home" or "not there," anywhere but at the scene of the lynching-a self-serving thought, but probably not true. The emotional impact of the image-the horror of it-leads them to dis-identify with the white mobs or spectators, and, vice versa, that dis-identification furthers the repulsion they feel. ${ }^{59}$ Yet that process of dis-identification might also lead them to exaggerate the historical distance between the lynching and present-day events, to feel that lynching and the racism it 
represents is safely ensconced in a past reality. They can, in turn, feel comforted by their own shock and disgust.

But what might an ethical white spectatorship entail, one that acknowledges white culpability for past crimes and collective responsibility for present-day injustices? One alternative might be for white viewers to feel shame as they look at these photographs. Many commentators on the Without Sanctuary website forum speak of the "shamefulness" of lynching, or feeling "ashamed" of this past. In doing so, they are acknowledging a personal relationship to past atrocities and even an identification with the white mobs or spectators. As Courtney Baker has argued, shame can lead to ethical action, as it "destabilizes one's comfort with oneself" and prompts one to reevaluate one's "social habits." ${ }^{60}$ Shame, in fact, was a common response among white Americans to the increasing publication of lynching photographs in anti-lynching campaigns and even in mainstream newspapers in the 1920s and 1930s, an emotional response that led not to the eradication of racist violence, but to its relative invisibility, as mobs could no longer perform public lynchings with impunity, and white communities hid the signs and remnants of their violence, including photographs, away ${ }^{61}$ In that sense, shame can produce a false reckoning with one's failings. As Martin Berger has written about Civil Rights-era photography, white shame in response to images of white brutality effected little actual political change. Instead, shame can work against empathy, as it leads one to focus on the self and one's own discomfort, rather than the suffering of others. Rather than work to rectify wrongs, the ashamed subject seeks to displace blame and to conceal his/her responsibility. ${ }^{62}$

Others have claimed that looking at atrocity photographs can be a potentially ethical and redemptive act if viewers recognize the common bonds of humanity that unite them with the victims in these images-in particular, what Courtney Baker calls the "elemental... human condition of vulnerability," or human suffering. To recognize the pain of another in this way is to engage in an active form of looking that Baker calls "humane insight." ${ }^{63}$ This insight challenges assumptions that the act of looking is an intrinsically objectifying act when the object of the look is "the other," that is, a colonizing gaze that denies the humanity and subjectivity of the sufferer. The risk of this approach, however, is that the lynching victim's suffering is universalized in a way that flattens the historical specificity of racist violence in the US, which can lead to uncritical approaches to racism. The photographs become iconographic in a different way, not as symbols of black suffering, but as representations of collective misery or, in turn, human barbarism. As such, the images become visual citations, or quotations, through which we can conceptualize any present-day or future atrocity. ${ }^{64}$ Some viewers of Without Sanctuary, for instance, drew analogies between lynching and terrorism after 9/11, homophobic violence, or anti-Arab violence, or between lynching photographs and the images of Abu Ghraib prisoners. ${ }^{65}$ The "primal narrative" of lynching, in this sense, is an elastic one which can be deployed for multiple purposes and with varying degrees of complexity. ${ }^{66}$ This form of insight risks decontextualizing the lynching victim to the point that the long history of black subjugation and white supremacy is obscured altogether, and there is no white reckoning with that past-which is why Life's inclusion of the Duck Hill photograph in its Family of Man photo-essay appears so jarring to us now. ${ }^{67}$ These uses ultimately can do a disservice to historical memory, contributing to a harmful misremembering that can create a kind of visual exploitation of the lynched body. 

same time, acknowledging the racial particularity of black suffering rooted in the histories of slavery and Jim Crow. Such an insight must feel a shared human vulnerability, a physical connection with others, while at the same recognizing differences in subjective experiences between self and other, differences contingent upon social position and one's relationship to history. That is, one can feel the suffering of another, approximately, while also knowing that one is not actually feeling it. Sympathy, in this regard, serves as a more useful term than empathy. It can be unethical to empathize in the sense of placing oneself in the position of others when one cannot possibly experience their suffering; to do so can deny one's own relative position of security. Sympathy, however, connotes feeling alongside with rather in place of.

Sympathy-and its cousin, compassion-have been critiqued as emotions laden with value judgments and implied hierarchies. They emerged in the seventeenth century to connote the feeling of placing oneself in the experience of another, and were viewed by Enlightenment thinkers such as David Hume and Adam Smith as essential for moral thinking and ethical action. ${ }^{68}$ By the nineteenth century, sympathy lay at the heart of sentimental humanitarianism, or the idea that what united humanity, and the human and animal world, was not intellect or reason, but its shared capacity to feel pain. Since sentimentalism was the province of middle-class and elite white Euro-Americans, of those who had the time and comfort, or the detachment from suffering, to suffer on behalf of others, it came to be associated with class and racial privilege. Sympathy soon connoted pity, the emotion of feeling for someone below one's station, rather than a feeling of shared pain among equals. In the twentieth century, psychologists replaced sympathy with empathy, from the German word "einfuhling," meaning to "feel into," which involves a process of imitation or simulation, of experiencing another's feelings as one's own by projecting one's own feelings into the experience of another. ${ }^{69} \mathrm{Feminist}$ and postcolonial scholars, however, have come to critique empathy, since it presumes that people respond to the same suffering in the same way, without acknowledging differences in historical or social experience and power. Empathy can also potentially obscure or erase the voices of marginalized groups. Indeed, the problem with "bearing witness" is that the witness, by implication, is granted authority to speak for another. In short, empathy recreates the same hierarchies that sympathy came to denote. ${ }^{70}$

In this light, sympathy and compassion warrant a resurrection, if we remember their etymological roots denoting both suffering (pathos/passion) and with (sym/com). Pathos involves an intensity of response that is both emotional and visceral, rooted in the original dual association of pathos with passion and passivity. While today we tend to understand passion as an intense, positive feeling toward an object, the word still retains an earlier notion of being acted upon, for instance, when we describe feeling passionate as being captivated or taken by something. In feeling pathos, then, one is reminded of one's physical vulnerability-one's passivity, the feeling of being acted upon-for grief or repulsion are bodily reactions as much as they are feelings. Our pathos thus forces a connection to the external world, which, when we are horrified, shocked, or saddened, has penetrated our subjective isolation. That loss of boundaries around the self and that awareness of the external world creates a new form of knowing which connects us to others. In that way, sympathy, unlike empathy, does not connote feeling the same as others or speaking from their position; rather, it suggests a 
looser connectivity, an approximation of fellow feeling, but a fellowship nonetheless. As Dorota Golanska has argued, this is what happens when we encounter the trauma of others. We can feel sympathy with others only when we feel our own vulnerability through an affective response to their suffering. But unlike empathy, that response acknowledges the differences between one's own position and that of the other. One feels, not in place of another, but alongside the other. In this sense, to witness is not to speak for another, but instead, implies that one has a connected, albeit not identical, experience of a traumatic event with another. ${ }^{71}$

Works of art can serve as critical objects to prompt a sympathetic response to trauma, since a function of art is to generate emotional responses and change perceptions, and art makes and conveys meaning through the sensations that it produces. Art can, in that way, enable emotional connections to others. ${ }^{72}$ Indeed, "einfuhling" was first used in reference to aesthetics in the 1870s, to conceptualize how people experience art and, through art, come to feel the perspectives and mental states of others. Just as we can "feel into" or simulate the feelings of others, we can experience the properties of art as our own because they produce affective reactions in us, much as the physical expressions or movements of other people can. ${ }^{73}$ Scholars of trauma have understood memorial art or memorial sites as functioning in a similar way. In encountering the suffering of others through art, the viewer experiences a milder or muted form of trauma. ${ }^{74}$

Atrocity photographs could intensify a sympathetic response since, due to their documentary realism, they create a virtual or mediated experience; one is in the scene, as a witness to the victim's suffering, while, at the same time, aware that is one removed from the scene. Indeed, we are moved toward a sympathetic response to the suffering in a photograph when we recognize the image as a representation of atrocity, rather than as a transparent reflection of a reality. ${ }^{75}$ "Accused/Blowtorch/Padlock" successfully makes viewers aware of the representational nature of the image through the way Williams breaks up the image and frames it, as well as through her text.

To understand this emotive effect of atrocity images, however, is to disrupt the emphasis we place on the visual authority of the photograph. That authority derived from a western ocular-centrism, which focused on the visual as the primary source of knowledge. We know this atrocity happened because we can see it. Instead, if we focus on the photograph's emotive power, the body becomes the primary vehicle for knowledge; we know the suffering of the victim because we ourselves feel an approximation of it in our affective reaction to the image. ${ }^{76}$ This is what Elizabeth Alexander means when she says that black memory "resides in the flesh" and is activated by witnessing scenes of black suffering. But white sympathy, even without the same racial identification, can also "reside in the flesh," though horror, disgust, and heartache, and spur an ethical engagement with historical memory. Of course, as has been shown, that affective response is conditioned not by the photograph itself, but by the context in which it is viewed, the text and framing, and the knowledge viewers bring to their encounter with the image, including references to other images. Williams' texts guides viewers toward a specific affective response through her framing of the image and the accompanying self-reflexive text. By commenting on her spectatorship of the photograph, she compels us to feel the pain of her encounter with the lynching photograph and to recognize our own spectatorship at the same time. 


\section{criticized for its un-reflective and voyeuristic display of the photographs, which were} exhibited on blank, white walls, without explanatory text beyond simple captioning. Subsequent exhibitions of the Without Sanctuary collection responded to these critiques by providing more context, including content about anti-lynching activism-all of which was meant to circumscribe viewers' responses to the images. These exhibits also sought to foster a self-reflexive spectatorship, drawing attention to the representation of the images as historical documents, rather than as transparent windows into the past, through interactive questions and through the exhibit design itself. ${ }^{77}$ For instance, cut-outs in the walls compelled viewers to watch each other view the photographs, creating an unsettling awareness of their own spectatorship. The effect was to foster a sympathetic engagement with the photographs.

Sympathy, because it involves a turn away from the self and toward a connection with others, is a precondition for ethical action. This view also rests on the theory that emotions are relational, that is, they are felt toward something or someone and promote connection to others. They are also expressive or performative in the sense that they generate effects- including a new knowledge of the world and a sense of responsibility for it..$^{78}$ This effect is what can lead Williams to scrawl "Somebody do Something!" beside a photograph of a lynching from fifty years ago and compel viewers to want to intervene.

Viewers' subjective relationship to the past atrocity will also shape their encounter with its representation. As noted above, black and white viewers encounter lynching photographs in palpably different ways. Yet, in my analysis of "Accused/Blowtorch/ Padlock," I have used the language of a single "viewer," or "we," as if there could be one definitive encounter with the piece, because it itself directs viewers toward a specific interpretation. The success of a piece like "Accused/Padlock/Blowtorch" is that it compels all viewers to take Williams' point of view as a black woman, to sympathize with her pain- and to bear witness to it. In that sense, to have an ethical encounter with lynching photographs is to understand them as both historical and not historical at the same time. Indeed, the erasure of historical particularity is not an unfortunate byproduct of historical memory; it is exactly how historical memory functions effectively. Our encounter with "Accused/Padlock/Blowtorch," which itself collapses past and present and compels us to interpret McDaniels' torture as ongoing, testifies to this process. In my analysis, I have used the present tense, just as Williams does; there is no other tense to use, as memory is not about the past but the present.

In this light, it is not coincidental that so many protests in the aftermath of high-profile murders of African Americans at the hands of police in the past few years have involved a pointed, sympathetic identification with the victims. In response to the death of Eric Garner in 2014, "I Can't Breathe" was printed on posters and t-shirtsGarner's final words, heard on the digital recording of his murder, as the police put him in the chokehold that killed him. "Hands Up, Don't Shoot" became a protest refrain in the aftermath of Michael Brown's death in Ferguson, Missouri, in 2014. "I am Trayvon" was plastered on hoodies and placards after the 2012 murder of Trayvon Martin, as was "I am Sandra Bland" after the mysterious death of Bland, held in custody after an arrest for a traffic violation in 2015. 

Alexander wrote in 1995 that the video of Los Angeles police officers beating Rodney King "activated" collective black identity, rooted in memories of black suffering, leading black viewers to feel themselves "implicated" in King's fate..$^{79}$ Williams had the same affective response to the lynching of Bootjack McDaniels. Something similar happened when video footage of police killings-of Garner, Philando Castile, and others -appeared across the internet and on television news in the past five years. As happened with high-profile killings in the 1980s, the murders were likened to "legal lynchings," the videos to lynching photographs. As Koritha Mitchell has written, "these videos often end up making a statement very similar to that conveyed by lynching photographs: This can be done to people of color because they are not true citizens" (emphasis in original). ${ }^{80}$ Commentators on the Without Sanctuary website forum have drawn similar connections.

But the historical memory of lynching may also prompt white viewers to interpret present-day images of police brutality against African-Americans sympathetically. In response to these images, Mitchell has lamented that "watching the brutalization of people of color fails to inspire empathy" in many white Americans..$^{81}$ Yet lynching photographs can create a historical context through which white viewers can interpret present-day acts of racist violence. As one teacher posted on the Without Sanctuary website forum: "I've been trying to get my class of $12^{\text {th }}$ graders, all white, to understand the underlying reasons for the protests [against police killings.]... I had the constant sense that I was not making any headway. I showed them this [site] today. They left class in stunned silence, their heads bowed. I think today I finally started to get through to them." ${ }^{22}$ What's more, perhaps surprisingly, a good number of white people were photographed wearing "I am Trayvon Martin" hoodies or carrying “We Can't Breathe" signs. At first glance, this is an offensive identification, as they appear ignorant and unfeeling about their advantaged social position as white persons in America. But it's hard to imagine that any white person who would wear a "I am Trayvon Martin" hoodie or who would carry a "We Can't Breathe" sign would not know this. Instead, their identification could be read as clumsy attempts to grapple with their affective response to the brutality they have witnessed, to mistake sympathy for empathy. This response, nevertheless, prompted them take some sort of ethical action -to do something-in this case, to protest. 


\section{NOTES}

1. Howard Kester, "Lynching by Blow Torch," part 7, Series A, Reel 13, National Association for the Advancement of Colored People Files, microfilm edition (hereafter NAACP Files); Chicago Defender, 17 April, 1937, 2; Memphis Press Scimitar, 14 April, 1937, 1-2; Time, 26 April 1937, 16-17.

2. Dora Apel, Imagery of Lynching: Black Men, White Women, and the Mob (New Brunswick, NJ: Rutgers University Press, 2004), 211-214; Elizabeth Hess, “Window Pain," Village Voice, 16 February 1991.

3. This association is a common one. As Susan Sontag has written in On Photography (New York: Anchor Books, 1977), 14-15, "Just as the camera is a sublimation of the gun, to photograph someone is a sublimated murder."

4. Leigh Raiford, "Photography and the Practices of Critical Black Memory" History and Theory 48 (December 2009), 112-129; On lynching as a metaphor, see Jonathan Markovitz, Legacies of Lynching: Racial Violence and Memory (Minneapolis: University of Minnesota Press, 2004), xvii.

5. E. Ann Kaplan, "Empathy and Trauma Culture: Imaging Catastrophe" in Empathy: Philosophical and Psychological Perspectives, eds. Amy Coplan and Peter Goldie (New York: Oxford University Press, 2011), 256, 270; Barbie Zelizer, Remembering to Forget: Holocaust Memory Through the Camera's Eye (Chicago: University of Chicago Press, 1998), 10-11; Frances Guerin and Roger Hallas, eds., The Image and the Witness: Trauma, Memory, and Visual Culture (New York: Wallflower Press, 2007), 6.

6. Kaplan, "Empathy," 257, 268, 275.

7. Citing the work of Ella Shohat and Robert Stam, Jonathan Markovitz, Legacies of Lynching, 35, discusses how "representations of oppressed groups are unavoidably caught up in a process whereby they stand for something greater than themselves."

8. Raiford, "Photography," 113.

9. On the social dimensions of memory, see: Maurice Halbswachs, On Collective Memory [1925] (Chicago: University of Chicago Press, 1992); Paul Connerton, How Societies Remember (New York: Cambridge University Press, 1989); David Middleton and Derek Edwards, eds., Collective Remembering (London: Sage Publications, 1990); James Fentress and Chris Wickham, Social Memory: New Perspectives on the Past (Oxford: Blackwell Publishers, 1992); Natalie Zemon Davis and Randolph Starn, "Introduction: Memory and Counter-Memory," Representations 26 (Spring 1989), 1-7; Barbie Zelizer, "Reading the Past Against the Grain: The Shape of Memory Studies," Critical Studies in Mass Communication 12 (June 1995), 214-239; On the relationship between history and memory, see Steven Knapp, "Collective Memory and the Actual Past," Representations 26 (Spring 1989), 123-149; Peter Burke, "History as Social Memory," in Thomas Butler, ed., Memory, History, Culture, and the Mind, (Oxford: Basil Blackwell, 1989); David Thelen, "Memory and American History," Journal of American History 75:4 (March 1989), 1117-1129. For more on lynching photographs and historical memory, see Amy Louise Wood and Susan Donaldson, "Lynching's Legacy in American Culture," Mississippi Quarterly 61: 1-2 (2008), 5-25.

10. This essay focuses on African-American and white responses to lynching photographs. Other groups-Native Americans, Mexicans, Chinese, and other immigrants-were the victims of lynchings throughout the nineteenth and twentieth centuries, but lynching does not stand as a "primal narrative" for these groups, nor was it central to their civil rights activism. There are a few photographs of white lynching victims, of various ethnicities, in the Without Sanctuary collection, but the vast majority of victims depicted are African Americans. For these reasons, the public commentary on lynching photographs has focused on black and white viewers.

11. Zelizer, Remembering to Forget, 10, 84-87; Roland Barthes, Camera Lucida: Reflections on Photography, translated by Richard Howard (New York: Hill and Wang, 1981), 76; John Taylor, Body 
Horror: Photojournalism, Catastrophe, and War (New York: New York University Press, 1998); Guerin and Hallas, eds., The Image and the Witness, $2,11$.

12. Zelizer, Remembering to Forget, 4-8; Astrid Eril and Ann Rigney, eds., Mediation, Remediation, and the Dynamics of Cultural Memory (New York: Walter de Gruyter, 2009), 1-5.

13. Susan Sontag, Regarding the Pain of Others (New York: Farrar, Straus, and Giroux, 2003), 22; James Polchin, "Not Looking at Lynching Photographs," Guerin and Hallas, eds., The Image and The Witness, 214.

14. Marianne Hirsch, "Surviving Images: Holocaust Photographs and the Work of Postmemory" in Barbie Zelizer, ed., Visual Culture and the Holocaust (New Brunswick, NJ: Rutgers University Press,), 231; Sontag, On Photography, 70; Barthes, Camera Lucida, 13-14; Guerin and Hallas, eds., The Image and the Witness, 11-12.

15. John Lewis, "Forward," in James Allen, Without Sanctuary: Lynching Photography in America (Santa Fe, NM: Twin Palm Publishers, 2000), 7. In the context of both lynching photographs and present-day images of police brutality, Koritha Mitchell has noted that black suffering is only acknowledged when it is seen, whereas many white Americans are quick to "sympathize" with white victims of gun violence without any visual evidence of this violence; in fact, news media outlets are likely to deem images of white victims of violence as too terrible, too indecent to show. This is true to a certain extent, yet, the responses of Lewis, Williams and other AfricanAmerican viewers of lynching photographs-as well as copious evidence of white responses to photographs of white suffering-belie Mitchell's point. See Mitchell, "What I Learned about Police Brutality Videos from Studying Images of Lynching," Vox, 28 July, 2016, https:// www.vox.com/2016/7/28/12241082/police-brutality-lynchings-self-care (accessed 8 March 2019).

16. This assessment is based on reading viewers' comments in guest books at exhibitions of Without Sanctuary in Atlanta, Georgia (2002) and Charlotte, North Carolina (2012), as well as online at www.withoutsanctuary.org. For quotations listed above, see visitors' comments, 14 April 2013, 25 August 2012, 19 November 2014, 20 November 2014, 20 February 2013, www.withoutsanctuary.org (accessed 11 March 2019).

17. Most photographs, like the one of Bootjack McDaniels, were taken by local, professional photographers to commemorate the event for the community, often for commercial profit, or, sometimes, by members of the mob with their amateur Kodaks. Rare are photographs taken by journalists or outside observers. See Amy Louise Wood, Lynching and Spectacle: Witnessing Racial Violence in America (Chapel Hill: University of North Carolina Press, 2009), 77.

18. For this point of view, see Grace Hale, "Exhibition Review," Journal of American History 89:3 (2002), 993-94; JoAnn Wypijewski, “Executioners' Songs," The Nation, 27 March 2000, 30, 34; Raiford, "Photography," 120; For an overview of critical reactions to Without Sanctuary, see Dora Apel, “On Looking: Lynching Photographs and the Legacies of Lynching after 9/11," American Quarterly 55 (2003): 464-466.

19. Sontag, On Photography, 20-21; Taylor, Body Horror, 14.

20. Martin Berger, Seeing Through Race (Berkeley: University of California Press, 2011), 72, makes this point about scenes of brutality captured in civil rights-era photography; see also Raiford, "Photography,"120; Susan Crane, "Choosing Not to Look: Representation, Repatriation, and Holocaust Atrocity Photography" History and Theory 47 (October 2008): 309-330.

21. These same challenges led to Susan Sontag's critique of photographs in her 1977 volume, On Photography. She later revised her understanding to find the redemptive power in looking in Regarding the Pain of Others, 110-111, in part because she considered the refusal to look a privilege of those in wealthy nations.

22. "Emory Asks Public to Help Decide Fate of Controversial Exhibit," Creative Loafing [Atlanta, GA], Dec. 9, 2000, 41. 
23. For more on these artists, see Raiford, "Photography," 112-129; Shawn Michelle Smith, "The Evidence of Lynching Photographs," in Dora Apel and Shawn Michelle Smith, Lynching Photographs (Berkeley: University of California Press, 2008), 28-32.

24. Quoted in the Montgomery Advertiser, 25 April, 2018,

https://www.montgomeryadvertiser.com/story/news/2018/04/25/without-sanctuary-and-howwe-remember-lynching/499641002/ (accessed Dec 30, 2018); on this point, see also Jason Morgan Ward, "The Legacy Museum: From Enslavement to Mass Incarceration; The National Memorial for Peace and Justice," American Historical Review 123: 4 (October 2018), 1272.

25. For more on how viewers in the past received and interpreted lynching photographs, see Wood, Lynching and Spectacle, especially, 75-76; 183-193.

26. Sontag, On Photography, 17-19.

27. Wood, Lynching and Spectacle, 212.

28. New York Times, 16 April 1937, 1; Time, 26 April 1937, 17.

29. Time, 26 April 1937, 17.

30. Life, 26 April 1937, 26. The only other white-owned newspaper I know of that published the image of Bootjack McDaniels was the Memphis Press-Scimitar, 14 April 1937, 2, which was highly unusual for a southern paper at the time. The Press-Scimitar, however, was fiercely anti-lynching. The black press covered both the lynching and the Gavagan Bill widely, though they did not publish images of the lynching at the time, presumably because they could not obtain copies. The Pittsburgh Courier, 24 April 1937, 1, published an image of the lynching site, with the bodies removed, and the Atlanta Daily World, 20 April 1937, 1, published Roosevelt Townes' mugshot to accompany their coverage of the lynching. White-run news outlets such as the Associated Press, Time, and Life, apparently purchased the images from the photographer. Yet when the NAACP tried to purchase them for its files, it found that the pictures had been distributed by Campbell's Studio in Grenada, Mississippi, but was told that it could not obtain any. Life magazine told the NAACP in a letter that "the pictures which we had were taken by someone who does not care to become a storm centre (sic) and has accordingly instructed us to refrain from giving his name to anyone." Life to the NAACP, 4 May 1937, Part 7, Series A, Reel 13, NAACP Files, Microfilm.

31. Time, 26 April 1937, 16.

32. Wood, Lynching and Spectacle, 197.

33. The exception was Time, 26 April 1937, 16-17, which did provide a summary of events, likely similar to the one read on the floor of the House.

34. Memphis Press Scimitar, 14 April 1937, 2

35. For more on anti-lynching activists' use of these images, see Wood, Lynching and Spectacle, 186-211.

36. Ibid., 204-207.

37. Edward Steichen, The Family of Man (New York: Museum of Modern Art, 1955; reprint 1983), 3.

38. Ibid.

39. On the Family of Man exhibit, see, Eric Sandeen, Picturing an Exhibit: The Family of Man and 1950s America (Albuquerque: University of New Mexico Press, 1995); John Szarkowski, "The Family of Man," Studies in Modern Art 4 (1994), 30; Kevin Salemme, "Chasing Shadows: Steichen's Dream of the Universal," History of Photography 29:4 (2005), 372-377.

40. Quoted in Sandeen, Picturing an Exhibit, 49-50.

41. Szarkowski, "The Family of Man," 30.

42. "Common Bonds of Man," Life, 14 February 1955, 132.

43. Interestingly, Life, 7 March 1955, 18-20, published only one Letter to the Editor in response to this page of the photo-essay. The letter referred only to the picture of Communists entering Shanghai and commented that the people in the photograph did not look "panicked."

44. Quoted in Deborah Willis and Howard Dodson, Black Photographers Bear Witness: 100 Years of Social Protest (Williamstown, MA: Williams College Museum of Art, 1989), 18. 
45. Kellie Jones, “In Their Own Image," Artforum International 29:3 (November 1990), 138.

46. New York Times, 14 April 1937, 52; New York Amsterdam News, 17 April 1937, 1.

47. Apel, Imagery of Lynching, 214.

48. Jones, "In Their Own Image,"138.

49. Hess, "Window Pain," 91.

50. Lucy Lippard, Mixed Blessings: New Art in a Multicultural America (New York: Pantheon Books, 1990), 37.

51. Christopher Waldrep, African Americans Confront Lynching: Strategies of Resistance from the Civil War to the Civil Rights Era (New York: Rowman and Littlefield, 2009), 120.

52. Markovitz, Legacies of Lynching, 46, 70-84.

53. Waldrep, African Americans Confront Lynching, 113-127.

54. Elizabeth Alexander, "'Can you be BLACK and Look at This?': Reading the Rodney King Video(s)" in The Black Public Sphere Collective, eds., The Black Public Sphere: A Public Culture Book(Chicago: University of Chicago Press, 1995), 81-98; this conception of black memory is similar to Marianne Hirsch's conception of "postmemory" to refer to the secondary trauma of descendants of Holocaust survivors, a trauma, she argues, that is activated through encounters with Holocaust photographs. Hirsch explains that, rather than desensitize postmemory survivors to the atrocity, repeated exposure to the images connects them more tightly to the experience of the older generation. See Marianne Hirsch, "Surviving Images: Holocaust Photographs and the Work of Postmemory," Yale Journal of Criticism 14 (2001), 218.

55. Hilton Als, "GWTW," in Without Sanctuary, 38.

56. Quoted in Apel, "On Looking," 465.

57. Hilton Als, “GWTW," 39; See also Raiford, "Photography," 126; Apel, “On Looking," 468.

58. Hilton Als, "GWTW," 39.

59. James Polchin, "Not Looking at Lynching Photographs," 213.

60. Courtney R. Baker, Humane Insight: Looking at Images of African American Suffering and Death (Urbana: University of Illinois Press, 2015), 65-66. For more on shame and lynching photographs, see Dora Apel, "Lynching Photographs and the Politics of Public Shaming," in Apel and Smith, Lynching Photographs, 43-78.

61. Wood, Lynching and Spectacle, 262-63; Apel, "Lynching Photographs," 45.

62. Berger, Seeing Through Race, 74-75.

63. Baker, Humane Insight, 13.

64. Zelizer, Remembering to Forget, 13, 203-09.

65. Polchin, "Not Looking," 214; Apel, "On Looking," 461, 473-74; Susan Sontag, "Regarding the Torture of Others," New York Times Magazine, 23 May 2004, 124-29; Luc Sante, "Tourists and Torturers," New York Times, 11 May 2004, A23.

66. Markovitz, Legacies of Lynching, 70.

67. Apel, "On Looking," 473-44; Martin Berger, Seeing Through Race, 67-68, points out that historically whites have been incapable of viewing black bodies in pain in universal terms.

68. Amy Coplan and Peter Goldie, eds., Empathy: Philosophical and Psychological Perspectives (Oxford University Press, 2011), x-xi; Dorota Golanska, Affective Connections: Toward a New Materialist Politics of Sympathy (New York: Rowman and Littlefield, 2017), 182-183.

69. Coplan and Goldie, Empathy, xii-xiii; Golanska, Affective Connections, 183.

70. Golanska, Affective Connections, 184-85.

71. Golanska, Affective Connections, 186-197; See also, Judith Butler, "Precarious Life, Vulnerability, and the Ethics of Cohabitation," Journal of Speculative Philosophy 26 (2012): 135-136.

72. Golanska, Affective Connections, 49-52; Jill Bennett, Empathic Visions: Affect, Trauma, and Contemporary Art (Stanford, CA: Stanford University Press, 2005), 1-21.

73. Coplan and Goldie, Empathy, xii.

74. Golanska, Affective Connections, 131; Bennett, Empathic Visions, 11. 
75. Bennett, Empathic Vision, 8-10; Polchin,"Not Looking," 213, similarly argues that we can avoid the "normalisation" of lynching photographs if we "resist [the] slippage between reality and image, between experience and representation"-in other words, by keeping in mind the artifice of the photograph; Berger, Seeing Through Race, 77, notes that psychological experiments have shown that viewers are more likely to respond sympathetically and be moved to act to photographs of suffering than when witnessing violence in real life.

76. Golanska, Affective Connections, 4-9; in this view, affect, experienced in the body, is not separate from cognition, but part and parcel of it.

77. Apel, "On Looking," 463; Polchin, "Not Looking," 207-210; for a defense of the original Ruth Horowitz Gallery showing, see Bettina Carbonell, "The Afterlife of Lynching: Exhibitions and the Re-Composition of Human Suffering," Mississippi Quarterly 62 (Winter 2008/Spring 2009), 197-215.

78. Coplan and Goldie, Empathy, ix; Sara Ahmed, "Affective Economies," Social Text, 79 (Vol 22, No 2) (Summer 2004), 117-139; Golanska, Affective Connections, 32-33; Kaplan.

79. Alexander, "Can You Be BLACK and Look At This?," 89.

80. Koritha Mitchell, "What I Learned;" David G. Embrick, "Two Nations, Revisited: The Lynching of Black and Brown Bodies, Police Brutality, and Racial Control in 'Post-Racial' Amerikkka," Critical Sociology 41 (2015), 835-843; Keisha N. Blain, "Ida B. Wells, Police Violence, and the Legacy of Lynching," Black Perspectives (July 8, 2016), www.aaihs.org/ida-b-wells-police-violence-andthe-legacy-of-lynching/ (accessed 7 August 2017).

81. Mitchell, "What I learned."

82. Forum, 19 March 2015, www.withoutsanctuary.org (accessed 11 March 2019).

\section{ABSTRACTS}

This paper traces the history of one specific photograph and its exhibition over time from the 1930s through the 1980s: that of the lynching of 'Bootjack' McDaniels, tortured to death by a white mob in Duck Hill, Mississippi, in 1937. I use that history to reflect more broadly on how lynching photographs have shaped popular consciousness about racist violence at different moments in time. They are able to do so, in good part, because of their iconographic qualities. These photographs, like many historical photographs, tend to detach past events from historical specificity and, subsequently, render the past into symbolic form, which allows new meanings to be imposed on them through the text and context that surround them. Those new meanings can direct viewers' emotional responses to the images. This process of recontextualization allows for a meaningful ethical engagement with both historical and present-day suffering. In these ways, lynching photographs have been crucial to the formation of black historical memories of violence and injustice in the United States. Through this same process of recontextualization, I argue, lynching photographs make it possible for white Americans to engage ethically with racist violence, in the past and the present, through what I call "sympathetic spectatorship," - an emotionally empathic form of looking that also involves an awareness of social difference.

\section{INDEX}

Keywords: Lynching, photographs, Without Sanctuary, Pat Ward Williams, Robert McDaniels, historical memory, sympathy, bearing witness 


\section{AUTHOR}

\section{AMY LOUISE WOOD}

Amy Louise Wood is a professor of history at Illinois State University, where she teaches courses in American cultural and intellectual history. She is the author of Lynching and Spectacle: Witnessing Racial Violence in America, 1890-1940 (University of North Carolina Press, 2009), and is currently writing a history of criminology and prison reform in the late nineteenth and early twentieth centuries. 